Advance Publication

\title{
INDUSTRIAL HEALTH
}

Received: April 16, 2021

Accepted: May 24, 2021

J-STAGE Advance Published Date: October 5, 2021 


\section{Letter to the Editor}

Title: Are Japanese actually taking leaves of absence?

Short running title: JAPANESE LEAVES OF ABSENCE

\section{Ken INOUE ${ }^{1 *}$, Yuri MURAYAMA ${ }^{2}$ and Noriyuki KAWANO ${ }^{3}$}

${ }^{1}$ Research and Education Faculty, Medical Sciences Cluster, and the Head of the Health Service Center, Kochi University, Japan

${ }^{2}$ Department of Psychiatry, Gunma University, Japan

${ }^{3}$ Center for Peace, Hiroshima University, Japan

*To whom correspondence should be addressed.

Ken Inoue, MD, PhD

Research and Education Faculty, Medical Sciences Cluster, Health Service Center, Kochi University

2-5-1, Akebono-cho, Kochi-shi, Kochi 780-8520, Japan

Tel: +81-88-844-8158, Fax: +81-88-844-8089

E-mail: ke-inoue@med.shimane-u.ac.jp (K. Inoue) 
Compared to the rest of the world, workers in Japan are known to annually take paid leave at a rather low rate. In 2001, 49.5\% of Japanese workers annually took paid leave, on average [according to a 2002 study], 47.1\% did so in 2006 [according to a 2007 study], $48.1 \%$ did so in 2011 [according to a 2012 study], 48.7\% did so in 2016 [according to a 2017 study], and $51.1 \%$ did so in 2017 [according to a 2018 study] ${ }^{1)}$. Japan is a world leader in overtime ${ }^{2}$. In order to remain healthy while working, Japanese need to properly take leaves of absence.

Since the percentage of Japanese workers who annually take paid leave showed no signs of decreasing, the government mandated that employers have workers take paid leave as part of a "reform of working patterns" in April 20193). Workers who earn 10 or more days of paid leave a year must take 5 days of paid leave per year. If a company is found to be in violation, it is subject to a fine of up to 300,000 yen. In 2019 [according to a 2020 study], $56.3 \%$ of workers who annually take paid leave ${ }^{1,4)}$. This is the highest percentage thus far and is presumably due to the effects of workers being mandated to take paid leave ${ }^{4)}$.

Although workers are mandated to take paid leave, do workers actually take time off of work while purportedly on leave? Average overtime has been found to exceed 100 hours a month, which is the limit on overtime (since any more overtime can lead to death from overwork), and workers have been found working on holidays ${ }^{5,6}$. In a society like this, workers are often unable to fully relax mentally and physically. In the recent past, tele-working (working from home) has been recommended due to the effects of COVID$19^{7)}$, but tele-working can blur the distinction between working hours and private time. In fact, working long hours at home may not be treated as overtime. Thus, companies and workers need to clearly distinguish between working hours and private time/rest and recreation.

We have concluded that the percentage of Japanese workers who take paid leave cannot be fully ascertained by studies of workers alone. Detailed circumstances need to be ascertained, e.g., did the worker not come to work while on leave, did the worker do no work at all while at home or on vacation, and was the worker not contacted at all by his or her employer. In order to ascertain these circumstances, a study indicative of realities at the national level should be conducted in cooperation with relevant agencies. Based on those results, workers and companies should be given appropriate advice and specific actions should be taken by worker and companies.

\section{References}

1) e-Stat. https://www.e-stat.go.jp/stat- 
$\underline{\text { search/files?page }=1 \& \text { layout }=\text { datalist } \& \text { toukei }=00450099 \& \text { tstat }=000001014004 \& \text { cyc }}$ $\underline{\mathrm{le}=0 \& \text { tclass } 1=000001022297 \& \text { tclass } 2=000001022298 \& \text { tclass } 3 \mathrm{val}=0}$ (in Japanese). Accessed March 21, 2021.

2) Ministry of Health, Labour and Welfare. https://www.mhlw.go.jp/wp/hakusyo/karoushi/19/dl/19-1-1.pdf (in Japanese). Accessed March 21, 2021.

3) Ministry of Health, Labour and Welfare. https://www.mhlw.go.jp/hatarakikata/salaried.html (in Japanese). Accessed May 19, 2021.

4) Topics of the Day (2021) Work Style Reform. Yomiuri Shimbun March 16, 2021,17 (in Japanese).

5) Takahashi M (2019) Sociomedical problems of overwork-related deaths and disorders in Japan. J Occup Health 61, 269-77.

6) Inoue K, Murayama Y, Hashioka S (2019) The risk of overwork death (karoshi) in the wake of natural disasters. BMJ opinion November 29, 2019. https://blogs.bmj.com/bmj/2019/11/29/the-risk-of-overwork-death-karoshi-in-thewake-of-natural-disasters/. Accessed November 29, 2019.

7) Ministry of Health, Labour and Welfare, https://www.mhlw.go.jp/content/000777425.pdf (in Japanese). Accessed May 19, 2021. 